\title{
Phytochemical profile of stem bark extracts of Khaya senegalensis by Gas Chromatography-Mass Spectrometry (GC-MS) analysis
}

\author{
Celestine Uzoma Aguoru, Christopher Gbokaiji Bashayi and Innocent Okonkwo Ogbonna*
}

Department of Biological Sciences, University of Agriculture, Makurdi, Benue State, Nigeria.

Received 26 July, 2016; Accepted 5 September, 2016

\begin{abstract}
The phytochemical constituents of stem bark extracts of Khaya senegalensis were isolated and analyzed using Gas Chromatography-Mass Spectrometry (GC-MS). A shade-dried stem bark of $K$. senegalensis was extracted using methanol and water as solvents. The main chemical compositions of the extracts were analyzed by GC-MS and preliminary phytochemical analysis was performed to confirm the various classes of active chemical. The chemical composition of methanolic stem bark extract of $K$. senegalensis included: 4-Hepten-3-one, 2, 6-Pyridinedicarboxylic acid, 3-0-methyl-d-glucose, myristic acid, pentadecanoic acid, n-Hexadecanoic acid, 9, 12-Octadecadienoic acid, and 11-Octadecenoic acid. Others are 9-Hexadecenoic acid, Stearic acid, I, E-11, Z-13-Octadecatriene, Cyclododecyne, Hexadecanoic acid, Ricinoleic acid, 13-Decosenoic acid, and 9-Hexadecenal. The Chemical composition of aqueous stem bark extract of $K$. senegalensis included 1, 2, 3-benzenetriol, n-Hexadecanoic acid, oleic acid, (Z)6,(Z)9-pentadecadeien-1-ol, 1,E-11,Z-13-octadecatriene, and 1-flourodecane. Other chemical constituents of the aqueous extract included 9-octadecanal, E-9-tetradecanal, and 2-methyl-Z, Z-3, 13octadecadienol. The molecular weight of these compounds ranged from low to high with carbon skeleton of between $\mathrm{C}_{7}$ and $\mathrm{C}_{37}$. Both aromatic and aliphatic compounds were identified. $K$. senegalensis contains alkaloid, saponin, tannins and flavonoids. A good number of bioactive compounds were present in the stem bark of $K$. senegalensis.
\end{abstract}

Key words: Aqueous extracts, metanolic extracts, GC-MS analysis, Khaya senegalensis, phytochemical profile.

\section{INTRODUCTION}

The use of traditional medicine is age long and inherent with prospects and challenges in many cultures in Africa. Even before the recorded history, medicinal plants had been used in the treatment of variety of ailments of mankind. These herbs had been very useful health remedies over the years and are currently in use in many parts of the world (Fabricant and Fansworth, 2001; Kumar et al., 2009; Al-Bayati et al., 2008). Some plant parts are used directly by these traditional medicine practitioners. Some are extracted before use or modified

*Corresponding author. Email: innocentia09@yahoo.com. Tel: +2348055706372.

Author(s) agree that this article remain permanently open access under the terms of the Creative Commons Attribution License 4.0 International License 
and combined before administration. In most cases, where they are extracted before application, crude extracts are used. Therefore one cardinal challenge to contend with is dosage and the other is cytotoxicity issue in traditional medicine cycle.

The use of medicinal plants in the treatment of ailments and diseases dates back to prehistory (Fabricant and Fansworth, 2001) and developing countries mostly rely on traditional medicines (Kumar et al., 2009). Traditional herbs as healers of diseases are important especially to local communities since they are easily accessible, easy to assemble and affordable to the people (Kumar et al., 2009). Various diseases including cancer and Alzheimer's disease had been reported to be treated with active compounds from plants (Kumar et al., 2009; Sheeja and Kuttan, 2007). Researches on phytochemical analyses of plant extracts in most cases correlate the chemical constituents of the plants with their pharmacological activity (Prachayasittikul et al., 2008; Costa et al., 2008; Al-Bayati and Al-Mola, 2008; Chen et al., 2008; Pesewu et al., 2008; Turker and Usta, 2008; Nyamai et al., 2016).

The therapeutic effects of medicinal plants are attributed to the phytochemicals in them including: flavonids, alkaloids, steroids, trepenoids, phenolic acids, tannins, saponins among others (Nyamai et al., 2016). These secondary metabolites exert antimicrobial activity through different mechanisms. Tannins have been found to form irreversible complexes with proline-rich protein (Shimada, 2006) resulting in the inhibition of cell protein synthesis. Herbs that have tannin as their main components are astringent in nature and hasten the healing of wounds and inflamed mucous membrane (Okwu and Okwu, 2004).

The biological function of flavonoid includes protection against allergies, inflammation, free radicals, platelet aggregation, microbes, ulcers, hepatotoxins and tumors (Okwu, 2004). These observations therefore support the use of $K$. senegalensis in herbal care remedies. The plant $K$. senegalensis, also contains alkaloids which are ranked the most efficient therapeutically significant plant substance. Pure isolated plant alkaloids and their synthetic derivatives are used as a basic medicinal agent for their analgesic, antispasmodic and bactericidal effects. Specifically, saponins have been reported to have an antimicrobial effect and could serve as precursors of steroidal substances with a wide range of physiological activities (Mahato et al., 1988).

Khaya senegalensis A. Juss (Meliaceae) is a popular medicinal plant among the Nupes and Yorubas in Nigeria. It belongs to the family Meliaceae (mahogany). The aqueous stem bark extract is traditionally used by these tribes in the treatment of malaria, jaundice, edema and headache (Aliyu, 2006; Makut et al., 2008). The Hausa and Fulani tribes in Northern Nigeria also use $K$. senegalensis as a remedy for several human and animal ailments (Aliyu, 2006). K. senegalensis is a large meliaceous tree native to the sub-Sahara savannah from Senegal to Uganda, and to some other parts of Africa. It is one of the most popular traditional medicines in Africa (Makut et al., 2008). It has medicinal properties for the effective management of several ailments including diarrhea (Kubmarawa et al., 2008).

Nigeria has a tropical climate and vegetation with a countless numbers of varieties of plant species. Most of these plants could have medicinal uses that are unexploited. Knowing the chemical composition of the compounds contained in the medicinal plant is a prerequisite to solving a major feat in traditional medicine operation. This could enable drug synthesis from such plants to take place. As a result, some problems relating to dosage, toxicities, and antagonisms could be solved. The aim of the present article therefore is to identify the phytochemical constituents of stem bark extracts of $K$. senegalensis used by the traditional people in the treatment of ailments, and to analyze the extracts using Gas Chromatography-Mass Spectrometry (GC-MS). To the best of our knowledge, researchers had used GC-MS to determine the chemistry of the active ingredients of stem bark extracts of $K$. senegalensis.

\section{MATERIALS AND METHODS}

\section{Plant}

Khaya senegalensis stem bark was collected from Manveh village, Ancho District of Akwanga Local Government of Nasarawa State, Nigeria. An initial quality evaluation of the plant material was carried out in the Department of Biological Sciences, Federal University of Agriculture, Makurdi by $\mathrm{C}$. U. Aguoru (PhD) and further at the National Research Institute for Chemical Technology (NARICT) Zaria to validate its authenticity. Stem bark of the plants were airdried under shade and pulverized into fine powder with mortar and piston and finally with a clean and dried grinding machine.

\section{Extraction procedure}

Maceration method was employed for the extraction of plant active constituents, and methanol (70\%) and water were used as solvents for the extraction of the plant materials (Salisu and Garba, 1997). Fifty grams of each of the powdered plant materials was put into $500 \mathrm{ml}$ conical flasks and $300 \mathrm{ml}$ of methanol was poured over it and left to stand for 3 days with intermittent stirring using a spatula. The conical flasks were covered with foil paper. After 3 days, the extracts were filtered and evaporated to dryness using rotary evaporator (Brinkmann, R110) and then dispensed into labeled sample vials and stored in the refrigerator at $4^{\circ} \mathrm{C}$ for subsequent use.

\section{Preliminary phytochemical determination}

The extracts of $K$. senegalensis stem bark was subjected to preliminary phytochemical analysis to test for the presence/absence of the various classes of active chemical constituent such as saponins, flavonoids, tannins, alkaloids, oxalate, phytate and cyanogenic glycoside using standard laboratory techniques as reported by Sood et al. (2012) and Chhetri et al. (2008). 


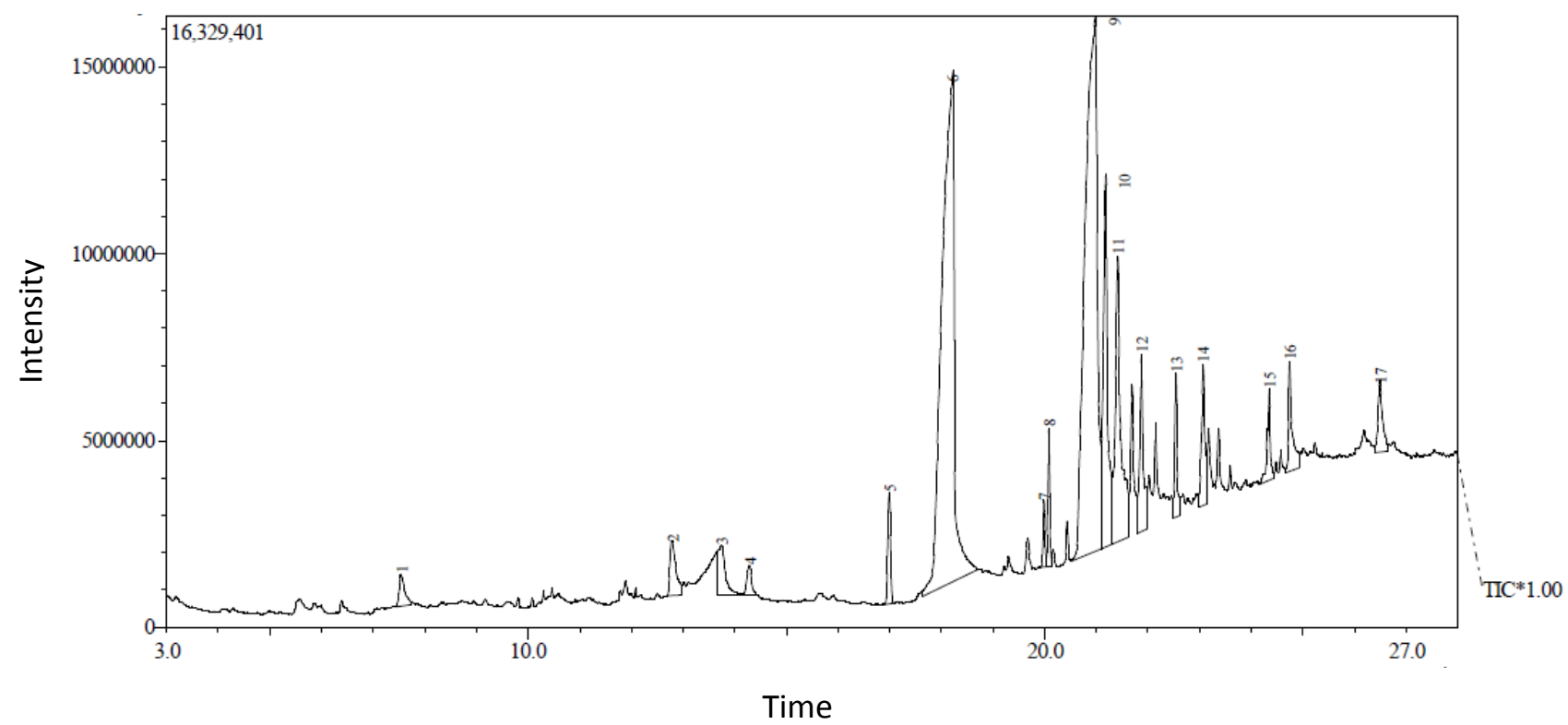

Figure 1. Total ion chromatogram of methanol extract of $K$. senegalensis.

Quantitative phytochemical analysis of $K$. senegalensis was also determined using standard biochemical techniques.

\section{GC-MS analysis}

The Chemical profiles of the extracts were determined by gas chromatography - mass spectrometry (GC-MS) model QP210 plus Shimadzu, Japan. The procedure for the analysis included the following details. Column temperature was set at $80^{\circ} \mathrm{C}$, injection temperature at $250^{\circ} \mathrm{C}$, pressure at $108.0 \mathrm{kPa}$, total flow was at 6.2 $\mathrm{ml} / \mathrm{min}$ and linear velocity at $46.3 \mathrm{~cm} / \mathrm{s}$. The start time was $3.00 \mathrm{~min}$ and end time was $28.00 \mathrm{~min}$. The compounds were identified using molecular weight and formula of the compounds and the retention time. Compound identification was obtained by comparing these values and the spectral data with those of authentic compounds from the library data of the corresponding compounds using automated Shimadzu software.

\section{RESULTS}

The total ion chromatogram of the methanol extract of $K$. senegalensis by GC-MS shows about seveenteen distinct peaks (Figure 1). Peak 6 and 9 show the highest percentage chemical composition. Each peak demonstrates a particular chemical compound. In Figure 2 , the total ion chromatogram of aqueous extracts of $K$. senegalensis shows about 13 distinct peaks. Peak 3 had the highest percentage chemical water could extract. Peaks 4 and 2 were also high in terms of percentage composition.

Tables 1 and 2 present the GC-MS peak report of methanol and aqueous extracts of $K$. senegalensis, respectively. The Tables cover the percentage availability and the retention time of each of the eluted compound.
For the methanol extracts, the highest compound identified was $\mathrm{n}$-Hexadecanoic acid (31.10 and 31.89\%) (Table 1) while the highest aqueous extracted compound was 3-O-methyl-d-glucose $(45.57 \%)$ (Table 2). The chemical composition of methanolic stem bark extract of K. senegalensis included: 4-Hepten-3-one, 2, 6Pyridinedicarboxylic acid, 3-O-methyl-d-glucose, Myristic acid, Pentadecanoic acid, n-Hexadecanoic acid, 9, 12Octadecadienoic acid, and 11-Octadecenoic acid (Table 3). Others are 9 - Hexadecenoic acid, Stearic acid, I, E11, Z-13-Octadecatriene, Cyclododecyne, Ricinoleic acid, 13-Decosenoic acid, and 9-Hexadecenal. The molecular weight of these compounds ranged from low to high with carbon skeleton of between $\mathrm{C}_{7}$ and $\mathrm{C}_{37}$. Both aromatic and aliphatic compounds were identified. The chemical composition of aqueous stem bark extract of $K$. senegalensis included 1, 2, 3-Benzenetriol, $\mathrm{n}$ Hexadecanoic acid, Oleic acid, (Z) 6, (Z) 9Pentadecadeien-1-ol, 1, E-11, Z-13-Octadecatriene, and 1-Flourodecane (Table 4). Other chemical constituents of the aqueous extract included 9-Octadecanal, E-9Tetradecanal, and 2-methyl-Z, Z-3, 13-Octadecadienol.

Alkaloid, saponin, tannins and flavonoid were present in both of the extracts (Tables 5 and 6). In both the methanol and aqueous extracts, flavonoid was the highest (32.14 and $25.20 \%$, respectively) occurring group of chemical.

\section{DISCUSSION}

The present study was designed to obtain the phytochemical profile of aqueous and methanolic extracts of $K$. senegalensis by GC-MS. The choice of the 
Table 1. GC-MS peak report of methanol extract of $K$. senegalensis.

\begin{tabular}{ccccc}
\hline Peak No. & R. Time & Area\% & Height $\%$ & A/H \\
\hline 1. & 7.543 & 0.88 & 1.09 & 7.49 \\
2. & 12.783 & 1.66 & 1.88 & 8.20 \\
3. & 13.738 & 1.69 & 1.68 & 9.36 \\
4. & 14.284 & 0.71 & 1.03 & 6.36 \\
5. & 16.992 & 1.54 & 3.80 & 3.77 \\
6. & 18.229 & 31.10 & 17.52 & 16.52 \\
7. & 19.989 & 0.65 & 2.27 & 2.67 \\
8. & 20.080 & 1.36 & 4.74 & 2.67 \\
9. & 20.973 & 31.89 & 18.28 & 16.23 \\
10 & 21.184 & 7.99 & 12.76 & 5.83 \\
11. & 21.414 & 8.07 & 9.78 & 7.68 \\
12. & 21.873 & 3.28 & 6.07 & 5.04 \\
13. & 22.538 & 1.71 & 4.91 & 3.24 \\
14. & 23.067 & 2.29 & 4.84 & 4.40 \\
15 & 24.347 & 1.45 & 3.09 & 4.35 \\
16. & 24.739 & 2.05 & 3.75 & 5.08 \\
17. & 26.487 & 1.68 & 2.48 & 6.32 \\
\hline
\end{tabular}

Table 2. GC-MS peak report of aqueous extract of $K$. senegalensis.

\begin{tabular}{ccccc}
\hline Peak & R. Time & Area\% & Height $\%$ & A/H \\
\hline 1. & 10.483 & 0.92 & 0.66 & 13.96 \\
2. & 17.993 & 17.40 & 16.25 & 10.78 \\
3. & 20.935 & 45.57 & 24.52 & 18.71 \\
4. & 21.137 & 11.90 & 18.44 & 6.49 \\
5. & 21.329 & 6.32 & 6.23 & 10.20 \\
6. & 21.788 & 4.52 & 7.34 & 6.20 \\
7. & 22.447 & 1.76 & 3.85 & 4.59 \\
8. & 22.974 & 1.38 & 2.24 & 6.18 \\
9. & 23.267 & 0.70 & 2.16 & 3.27 \\
10. & 24.265 & 2.92 & 6.86 & 4.28 \\
11 & 24.656 & 1.15 & 2.63 & 4.41 \\
12. & 26.081 & 1.67 & 3.55 & 4.74 \\
13. & 26.396 & 3.79 & 5.25 & 7.27 \\
\hline
\end{tabular}

extracting solvents (methanol and water) reflected how the local communities in the traditional treatments of ailments utilize the plants. The utilization of this plant for traditional medicine by the people also predicted that the plant could have some bioactive ingredients. The research of Kubmarawa et al. (2008) also supported the claim that extracts from the plant is used for the treatment of bacterial and fungal infections. This was one of the reasons that motivated our search for the actual chemical contained in the extracts.

Both the methanolic and aqueous extracts had many chemicals identified using retention time, relative percentage of the compound, molecular weight and molecular formula. The chemical compounds isolated from the methanolic extracts were mostly acidic including: 2, 6-Pyridinedicarboxylic acid, myristic acid, pentadecanoic acid, n-hexadecanoic acid, 9, 12octadecadienoic acid, and 11-octadecenoic acid. Others were 9-hexadecenoic acid, stearic acid, hexadecanoic acid, ricinoleic acid and 13-decosenoic acid. The other classes of compounds isolated were 4-Hepten-3-one, 3O-methyl-d-glucose, I, E-11, Z-13-Octadecatriene, Cyclododecyne, and 9-Hexadecenal. Some of these chemicals especially the acids have been demonstrated 


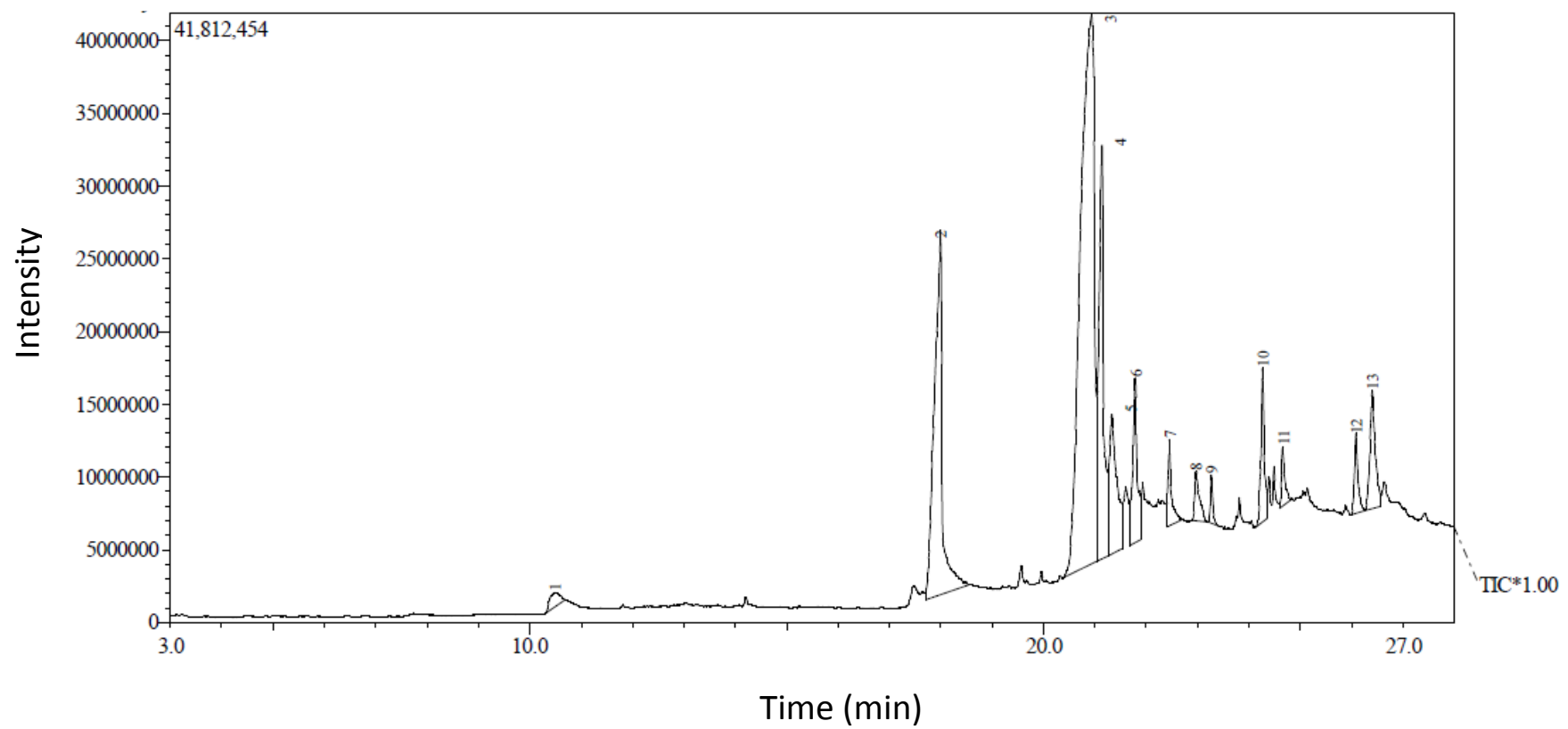

Figure 2. Total ion chromatogram of aqueous extract of $K$. senegalensis.

Table 3. Chemical composition of the methanol extract of $K$. senegalensis as identified by GC-MS.

\begin{tabular}{lclc}
\hline Name & Mol. weight & Formula & Structure number \\
\hline 4-Hepten-3-one & 126 & $\mathrm{C}_{8} \mathrm{H}_{14} \mathrm{O}$ & 1 \\
2, 6-Pyridinedicarboxylic acid & 167 & $\mathrm{C}_{7} \mathrm{H}_{5} \mathrm{NO}_{4}$ & 2 \\
3-O-methyl-d-glucose & 194 & $\mathrm{C}_{7} \mathrm{H}_{14} \mathrm{O}_{6}$ & 3 \\
Myristic acid & 228 & $\mathrm{C}_{14} \mathrm{H}_{28} \mathrm{O}_{2}$ & 4 \\
Pentadecanoic acid & 270 & $\mathrm{C}_{17} \mathrm{H}_{34} \mathrm{O}_{2}$ & 5 \\
n-Hexadecanoic acid & 256 & $\mathrm{C}_{16} \mathrm{H}_{32} \mathrm{O}_{2}$ & 6 \\
9, 12-Octadecadienoic acid & 294 & $\mathrm{C}_{19} \mathrm{H}_{32} \mathrm{O}_{2}$ & 7 \\
11- Octadecenoic acid & 296 & $\mathrm{C}_{19} \mathrm{H}_{36} \mathrm{O}_{2}$ & 8 \\
9 - Hexadecenoic acid & 254 & $\mathrm{C}_{16} \mathrm{H}_{30} \mathrm{O}_{2}$ & 9 \\
Stearic acid & 284 & $\mathrm{C}_{18} \mathrm{H}_{36} \mathrm{O}_{2}$ & 10 \\
I, E-11, Z-13-Octadecatriene & 248 & $\mathrm{C}_{18} \mathrm{H}_{32}$ & 11 \\
Cyclododecyne & 164 & $\mathrm{C}_{12} \mathrm{H}_{20}$ & 12 \\
Ricinoleic acid & 298 & $\mathrm{C}_{18} \mathrm{H}_{32} \mathrm{O}_{3}$ & 13 \\
13-Decosenoic acid & 338 & $\mathrm{C}_{22} \mathrm{H}_{42} \mathrm{O}_{2}$ & 14 \\
9-Hexadecenal & 238 & $\mathrm{C}_{16} \mathrm{H}_{30} \mathrm{O}$ & 15 \\
\hline
\end{tabular}

${ }^{*}$ As in Figure 3

to be bioactive (Shittu et al., 2007; Nyamai et al., 2016). The acidic organic chemical composition of aqueous stem bark extract of $K$. senegalensis included $n$ Hexadecanoic acid and Oleic acid. The alcoholic groupswere 2-methyl-Z, Z-3, 13-Octadecadienol, 1, 2, 3 Benzenetriol, and (Z) 6, (Z) 9-Pentadecadeien-1-ol. Other chemical constituents of the aqueous extract included 9Octadecanal, E -9-Tetradecanal, 1 E-11, Z-13-
Octadecatriene and 1-Flourodecane. There are reports of phenols (Proestos et al., 2008) and carboxylic acids (Proestos et al., 2005) being responsible for the antimicrobial activity in medicinal plants.

In the present study, qualitative and quantitative phytochemical screenings of $K$. senegalensis for the various classes of compounds show the presence of alkaloid, saponin, tannins and flavonoid in both of the 
Table 4. Chemical composition of the aqueous extract of $K$. senegalensis as identified by GC-MS.

\begin{tabular}{lclc}
\hline Name & Mol. weight & Formula & Structure number* \\
\hline 1,2,3-Benzenetriol & 126 & $\mathrm{C}_{6} \mathrm{H}_{6} \mathrm{O}_{3}$ & 16 \\
n-Hexadecanoic acid & 256 & $\mathrm{C}_{16} \mathrm{H}_{32} \mathrm{O}_{2}$ & 17 \\
Oleic acid & 282 & $\mathrm{C}_{18} \mathrm{H}_{32} \mathrm{O}_{2}$ & 18 \\
$(\mathrm{Z})$ 6, (Z) 9-Pentadecadeien-1-ol & 224 & $\mathrm{C}_{15} \mathrm{H}_{28} \mathrm{O}$ & 19 \\
1, E-11, Z-13-Octadecatriene & 248 & $\mathrm{C}_{18} \mathrm{H}_{32}$ & 11 \\
1-Flourodecane & 160 & $\mathrm{C}_{10} \mathrm{H}_{21} \mathrm{~F}$ & 20 \\
9-Octadecenal & 266 & $\mathrm{C}_{18} \mathrm{H}_{34} \mathrm{O}$ & 21 \\
E-9-Tetradecanal & 210 & $\mathrm{C}_{14} \mathrm{H}_{26} \mathrm{O}$ & 22 \\
2-methyl-Z, Z-3, 13-Octadecadienol & 280 & $\mathrm{C}_{19} \mathrm{H}_{36} \mathrm{O}$ & 23 \\
\hline
\end{tabular}

${ }^{*}$ As in Figure 3

\begin{tabular}{clc}
$\begin{array}{l}\text { Table } \\
\text { senegalensis. }\end{array}$ & Qualitative phytochemical & screening of $K$. \\
S/No & $\begin{array}{l}\text { Phytochemical composition } \\
\text { from qualitative Screening }\end{array}$ & K. senegalensis \\
\hline 1 & Tannin & + \\
2 & Oxalate & - \\
3 & Phytate & - \\
4 & Saponin & + \\
5 & Glycoside & - \\
6 & Alkaloid & + \\
7 & Trypsin & - \\
8 & Flavonoid & + \\
\hline
\end{tabular}

Key: + Present, - Absent.

Table 6. Quantitative phytochemical analysis of $K$. senegalensis.

\begin{tabular}{lcc}
\hline Constituents & Methanol & Aqueous \\
\hline Tannin $(\mathrm{mg} / 100 \mathrm{~g})$ & $+(0.55)$ & $+(0.53)$ \\
Oxalate $(100 \mathrm{mg} / 100 \mathrm{~g})$ & - & - \\
Phytate $(\mathrm{mg} / 100 \mathrm{~g})$ & - & - \\
Saponin $(\%)$ & $+(20.06)$ & $+(10.02)$ \\
Cynogenic & - & - \\
Glycoside $(\mathrm{mg} / 100 \mathrm{~g})$ & - & - \\
Alkaloid $(\%)$ & $+(22.28)$ & $+(8.45)$ \\
Trypsin $(\mathrm{Tul} / \mathrm{mg})$ & - & - \\
Flavonoid $(\%)$ & $+(32.14)$ & $+(25.20)$ \\
\hline
\end{tabular}

Key: + Present, - Absent.

extracts. Olmo et al. (1997) and Kubmarawa et al. (2008) also reported the presence of alkaloid, saponin and tannin in the stem bark extracts of $K$. senegalensis although they did not determine the individual chemicals as we have done in the present study using GC-MS. Some of the metabolites of the stem bark extracts of $K$. senegalensis have been reported to be responsible for antimicrobial activity Kumar et al. (2009). 
<smiles>C/C=C/C(=O)CC</smiles><smiles>O=C(O)c1cccc(C(=O)O)n1</smiles><smiles>COC1C(O)C(O)OC(CO)C1O</smiles><smiles>CCCCCCCCCCCCCC(=O)O</smiles><smiles>CCCCCCCCCCCCCCCC(=O)O</smiles><smiles>CCCCCC=CCCC=CCCCCCCCC(=O)O</smiles><smiles>CCCCCCC/C=C/CCCCCCCCCC(=O)O</smiles><smiles>CCCC/C=C/CCCCCCCCCC(=O)O</smiles><smiles>CCCCCCCCCCCCCCCCCC(=O)O</smiles><smiles>C=CCCCCCCCC/C=C/C=C/CCCCCCCCCCCC(O)C/C=C/CCCCCCC(=O)O</smiles><smiles>C1#CCCCCCCCCCC1</smiles>

12<smiles>CCCCCCCCCCCCCCCCCCCCCC(=O)O</smiles><smiles>CCCCCC/C=C/CCCCCCCC=O</smiles> 
<smiles>Oc1cccc(O)c1O</smiles>

16<smiles>CCCCCCCCCCCCCCCCCC(=O)O</smiles>

18<smiles>CCCCCC=CCC=CCCCCCO</smiles>

19<smiles>CCCCCCCCCF</smiles><smiles>CCCCCCCC/C=C/CCCCCCCC=O</smiles>

21<smiles>CCCC/C=C/CCCCCCCC=O</smiles><smiles>CCCCC=CCCCCCCCCC=CC(C)CO</smiles>

Figure 3. Chemical structures of extracts of $K$. senegalensis as identified by GC-MS.

\section{Conclusion}

Our present study shows that a good number of organic compounds are present in the stem bark of $K$. senegalensis and that these compounds account to a great extent for the claimed and reported ethno medicinal and bioactive potentials of the plant.

\section{Conflict of interest}

The authors have not declared any conflict of interest

\section{REFERENCES}

Al-Bayati FA, Al-Mola HF (2008). Antibacterial and antifungal activity of different parts of Trubulus terrestris L. growing in Iraq. J. Zhejiang UnivSci. B. 2(9):154-159.
Aliyu BS (2006). Common ethnomedicinal plants of the Semarids Region of West Africa, their description and phytochemicals. Triumph Publishing Company Limited Kano, Nigeria. pp. 199-200.

Chen IN, Chang CC, Wang CY, Shyu YT, Chang TL (2008). Antioxidant and antimicrobial activity of Zingiberaceae plants in Taiwan. Plant Foods Human Nutr. 63:15-20.

Chhetri HP, Yogol NS, Sherchan J, Anupa KC, Mansoor S, Thapa P (2008). Phytochemical and antimicrobial evaluations of some medicinal plants of Nepal. Kathmandu University J. Sci. Eng. Technol. 1:49-54.

Costa ES, Hiruma-Lima CA, Limo EO, Sucupira GC, Bertolin AO, Lolis SF, Andrade FD, Vilegas W, Souza-Brito AR (2008). Antimicrobial activity of some medicinal plants of Cerrado, Brazil. Phytother. Res. 22:705-707.

Fabricant DS, Fansworth NR (2001). The value of plants used in traditional medicine for drug discovery. Environ. Health Perspect. 109:69-75

Kubmarawa D, Khan ME, Punah AM, Hassan M (2008). Phytochemical screening and antimicrobial efficacy of extracts from Khaya senegalensis against human pathogenic bacteria. Afr. J. Biotechnol. $7(24): 23-25$.

Kumar A, llavarasan R, Jayachandran T, Decaraman M, Aravindhan P, 
Padmanabhan N, Krishman MRV (2009). Phytochemicals investigation on a tropical plant, Syzgium cumini from Kattuppalayam, Erode District, Tamil Nadu, South India. Pakistan J. Nutri. 8(1):83-85.

Mahato SB, Nandy AK, Roy G (1988). Triterpenoid saponins. Phytochem. 27:3037-3067.

Makut MD, Gyar GP, Pennap AP (2008). Phytochemical screening and antimicrobial activity of the ethanolic and methanolic eatracts of the leaf and barks of Khaya senegalensis. Afr. J. Biotechnol. 7:12161219.

Nyamai DW, Arika W, Ogola PE, Njagi ENN, Ngugi MP (2016). Medicinally important phytochemicals: An updated research avenue. Research and Reviews: J. Pharmacogn. Phytochem. 4(1):35-49.

Okwu DE (2004). Phytochemicals and vitamins content of indigenous spices of South Eastern Nigeria. J. Sustain. Agric. Environ. 6:30-34.

Okwu DE, Okwu ME (2004). Chemical composition of Spondias mombia Linn plant parts. J. Sustain. Agric. Environ. 6:140-147.

Olmo LR, Da Silva MF, Das GF, Fo ER, Vieria PC, Fernandes JB, Pinheiro AL, Vilela EF (1997). Limonoids from leaves of Khaya senegalensis. Phytochemistry 44:1157-1165.

Pesewu GA, Cutler RR, Humber DP (2008). Antibacterial activity of plants used in traditional medicine of Ghana, with particular reference to MRSA. J. Ethnopharmacol. 116:102-111.

Prachayasittikul S, Buraparuangsang $P$, Worachartcheewan $A$, Isarankura-Na-Ayudhya C, Ruchirawat S, Prachayasittikul V (2008). Antimicrobial and antioxidant activity of bioreactive constituents from Hydnophytum formicarum Jack. Molecules 13:904-921.

Proestos C, Boziaris IS, Kapsokefalou M, Komaitis M (2008). Natural antioxidant constituents from selected aromatic plants and their antimicrobial activity against selected pathogenic microorganisms. Food Technol. Biotechnol. 46:151-156.

Proestos C, Chorianopoulos N, Nychas GJ, Komaitis M (2005). RPHPLC analysis of the phenolic compounds of plant extracts. Investigation of their antioxidant capacity and antimicrobial activity. J. Agric. Food Chem. 53:1190-1195.
Salisu L, Garba S (1997). Phytochemical screening and insecticidal activity of Hyptis sauveolens and Striga hermonthica. Best J. 5(1):160-163.

Sheeja K, Kuttan G (2007). Activation of cytotoxic T lymphocyte responses and attenuation of tumor growth in vivo by Andrographispaniculata extract and andrographolide. Immunopharma-col Immunotoxicol. 29:81-93.

Shimada T (2006). Salivary proteins as a defense against dietary tannins. J. Chem. Ecol. 32(6):1149-1163.

Shittu LAJ, Bankole MA, Ahmed T, Bankole MN, Shittu RK, Saalu CL, Ashiru OA (2007). Antibacterial and antifungal activities of essential oils of crude extracts of Sesame radiatum against some common pathogenic microorganisms. Iran J. Pharmacol. Ther. 6:165-170.

Sood A, Kaur P, Gupta R (2012). Phytochemical screening and antimicrobial assay of various seeds extract of Cucurbitaceae family. Int. J. Appl. Bio. Pharm. Technol. 3(3):401-409.

Turker AU, Usta C (2008). Biological screening of some Turkish medicinal plants for antimicrobial and toxicity studies. Nat. Prod. 22:136-146. 